\title{
The Thioredoxins Protein System: a Key Target in Perinatal Asphyxia
}

\author{
Francisco Capani ${ }^{1,2,3,}$, Tamara Logica Tornatore ${ }^{1}$, Eduardo Blanco ${ }^{5}$, Marìa Inés Herrera ${ }^{1,4}$, \\ Rodolfo Kolliker ${ }^{1}$ and George Barreto ${ }^{6}$
}

${ }^{1}$ Instituto de Investigaciones Cardiológicas (ININCA), Facultad de Medicina, UBA-CONICET, Marcelo T. de Alvear 2270, C1122AAJ, Ciudad de Buenos Aires, Argentina

${ }^{2}$ Departamento de Biología, UAJFK, C1197AAR, Ciudad de Buenos Aires, Argentina

${ }^{3}$ Investigador Asociado, Universidad Autónoma de Chile

${ }^{4}$ CIPP, Facultad de Psicología, Universidad Católica Argentina

${ }^{5}$ Unidad de Gestión Clínica de Salud Mental, Laboratorio de Medicina Regenerativa, Instituto de Investigación Biomédica de Málaga (IBIMA), Hospital Universitario Regional de Málaga, Universidad de Málaga Málaga, Spain; Departament de Pedagogia i Psicologia, Facultat d'Educació, Psicologia i Treball Social, Universitat de Lleida Lleida, Spain

${ }^{6}$ Departamento de Nutrición y Bioquímica, Facultad de Ciencias, Pontificia Universidad Javeriana, Bogotá D.C., Colombia

\begin{abstract}
Hypoxia during birth is one of the leading childhood mortality worldwide and results in many neurodisabled survivors. Several lines of evidence demonstrated that reactive oxygen species are the final step in the metabolic disorders produced by a deficit of oxygen. However, any specific therapy has been effective to ameliorate the devastating consequences of perinatal asphyxia. In the last few years, the Thioredoxin Family Protein has emerged as a key player in the regulation of the redox state of the cells in normal and pathological conditions. This review summarizes new insight of the role of Trxs, Prxs and Grxs in physiopathology of perinatal asphyxia.
\end{abstract}

Keywords: Trxs protein family, Perinatal asphyxia, Neuroprotection, Redox regulation, Central nervous system, Retina.

\section{PERINATAL ASPHYXIA}

\subsection{Overview}

Perinatal asphyxia (PA) is characterized by an acute or subacute brain injury due to asphyxia and is considered one of the most frequent causes of morbidity and mortality in term and pre-term neonates, accounting for $23 \%$ of neonatal deaths globally [1]. As many as a million deaths worldwide might be caused by PA. Following PA, approximately $45 \%$ of newborns die and $25 \%$ have permanent neurological deficits including cerebral palsy, mental retardation, developmental disability, learning disabilities, visual impairments, hearing problems, and different issues in school readiness [2].

During early development, brain injury results in significant damage in different areas of the central nervous system (CNS) such as: cortex, hippocampus,

Address correspondence to this author at the Instituto de Investigaciones Cardiológicas (ININCA), UBA, CONICET, Marcelo T. de Alvear 2270, C1122AAJ, Buenos Aires, Argentina; Tel/Fax: +5411 4508 3886/8;

E-mail: franciscocapani@hotmail.com; fcapani@fmed.uba.ar neostriatum, cerebellum and substantia nigra [3]. The type and distribution of human brain lesions differ markedly between premature and term newborns, likely as a consequence of the stage of brain maturation and subsequent regional vulnerability, as described in several previous studies [4-6]. The neonatal brain, with its high concentrations of unsaturated fatty acids, high rate of oxygen consumption, low concentrations of antioxidants, and availability of redox-active iron, is particularly vulnerable to oxidative damage [7]

\subsection{Models of Perinatal Asphyxia}

Different model of PA has been used for many laboratories in the world. One of them is a murine model of PA. In this model uterus horns are isolated through an abdominal incision and placed in a water bath at $37^{\circ} \mathrm{C}$ during different period of time. According of the rate of survival, PA is classified in: mild PA (15 minutes, $100 \%$ of survival), moderate (19 minutes of PA, $50 \%$ of survival) and severe (20 minutes of PA, 10 $\%$ of survival). Following PA, uterus horns are opened, pups are removed and stimulated to breathe by performing tactile intermittent stimulation with pieces of 
medical wipes until regular breathing was established and then animals were left to recover for $1 \mathrm{~h}$ under a heating lamp. When their physiological conditions improved, they are given to surrogate mothers that had delivered normally within the last $24 \mathrm{~h}$. This PA model has three main advantages: first, it mimics the asphyxia just in the moment of delivery; second, it allows for the studying of both the short- as well as the long-term effects, since it is a non-invasive procedure; and third, it is easily reproducible across laboratories. The most obvious and serious short-term consequence of PA observed within this model is the mortality. Asphyxia period longer than 20 min generates an ATP deficit that leads to the consequent activation of anaerobic glycolysis and the accumulation of extracellular acidosis in the extracellular compartments [8]. Prolonged PA leads to an increase in expression of the hypoxia inducible factor (HIF-1) and a decrease of transcription and translation in general terms [9]. Reoxygenation is associated with cell death, probably induced by glutamate over-activation and excessive reactive oxygen species (ROS) release [8, 9]. Rats subjected to asphyxia for $20 \mathrm{~min}$ at $37^{\circ} \mathrm{C}$, and monitored by microdialysis, showed chronic defects in neurotransmitters, such as a decrease in dopamine, aspartate and glutamate release [9]. In addition, an increase in nitric oxide (NO) levels in the neostriatum and neocortex, both at short- and long-term periods was extensively described [10].

Long term consequences after 30 days of PA include modifications in cytoskeletal organization [11, 13]. After 6 months of PA proteins misfolding triggers an increment in protein ubiquitination levels, and synaptic degeneration [9, 11]. Moreover, different behavioral deficits such as exploration of new environments, spatial reference and working memory were observed 3 months after PA [12]. However, this $\mathrm{PA}$ model fails in the proper determination of the exact grade of neuronal damage since the PA is induced when rats do not have the brain totally developed and neurons are more resistant to the oxygen deprivation. Cerebral hypoxia-ischemia in 7-day-old rats is another murine model of PA frequently used [14, 15]. Basically consists in the ligation of the right common carotid artery, which remains occluded permanently. Whereas the cerebral blood flow normalizes rapidly, this produces an ischemic condition in the brain, which eventually leads to a focal hypoxia. This focal hypoxia is followed by exposure of rat pup to an anoxic environment for 3 minutes causing a global hypoxia. This model displays some features that do not correlate to the cases of PA suffered during human delivery.
First, at postnatal day 7 the rat is lissencephalic, in contrast to the gyrencephalic human brain [16]. Also, under the model conditions, ligation of the common carotid artery leads to unilateral regional reduction of cerebral blood flow; thus, the distribution of the brain injury caused by the experimental model does not correspond to human cases of severe hypoxicischemic encephalopathy [15]. The multi-organ involvement, one of the main characteristic after severe clinical asphyxia, is not seen after exposure to the experimental model. However, this model presents several advantages: (a) low-cost; (b) easily reproducible; (c) high rate of long-term survival (90\%), allowing the evaluation of neurological functional and neuropathological outcomes; (d) postnatal day 7 , the rat's brain corresponds histologically to that of a nearterm human fetus of 32-34 weeks, meaning that the cerebral cortical neuronal layering is complete, the germinal matrix is involuting, and white matter has undergone some myelination $[17,18]$. (Table 1)

Table 1: Comparison Among Main Features of Murine Perinatal Asphyxia Model

\begin{tabular}{|c|c|c|}
\hline & $\begin{array}{c}\text { Global Perinatal } \\
\text { Asphyxia }\end{array}$ & Global Hypoxia-Ischemia \\
\hline Procedure & $\begin{array}{l}\text { Non invasive. Place } \\
\text { animal in water bath } \\
\text { at } 37 \mathrm{C} \text {. } \\
\text { Easily reproducible }\end{array}$ & $\begin{array}{l}\text { Invasive. } \\
\text {-Ligation of the right common } \\
\text { carotid artery, which remains } \\
\text { occluded } \\
\text {-Exposure of rat pup to an } \\
\text { anoxic environment for } 3 \\
\text { minutes causing a global } \\
\text { hypoxia. } \\
\text { Easily reproducib }\end{array}$ \\
\hline Age of pups & New born & 7 days old \\
\hline $\begin{array}{l}\text { Rate of } \\
\text { survival }\end{array}$ & $\begin{array}{l}\text { Related to the grade } \\
\text { of asphyxia (100\% } \\
\text { in mild asphyxia 3\% } \\
\text { in severe asphyxia) }\end{array}$ & $90,00 \%$ \\
\hline $\begin{array}{l}\text { Brain } \\
\text { damage }\end{array}$ & $\begin{array}{l}\text { Related to the grade } \\
\text { of asphyxia }\end{array}$ & Severe damage \\
\hline $\begin{array}{l}\text { Clinical } \\
\text { correlation }\end{array}$ & $\begin{array}{l}\text { Reproduces } \\
\text { umbilical circular } \\
\text { cordon. Multiorgan } \\
\text { involvement }\end{array}$ & Grade of brain damage \\
\hline $\begin{array}{l}\text { Experimental } \\
\text { possibilitie }\end{array}$ & $\begin{array}{l}\text { Short and long term } \\
\text { studies }\end{array}$ & Short and long term studies \\
\hline $\begin{array}{l}\text { Brain } \\
\text { maturity }\end{array}$ & $\begin{array}{l}\text { Corresponds } \\
\text { histologically to a pre } \\
\text { term human fetus of } \\
28-30 \text { weeks }\end{array}$ & $\begin{array}{l}\text { Corresponds histologically to } \\
\text { that of a near-term human } \\
\text { fetus of } 32-34 \text { weeks, }\end{array}$ \\
\hline
\end{tabular}




\subsection{Physiopathology}

Different mechanisms of injury have been proposed for the immature brain versus the adult brain. Most obvious difference is that apoptotic mechanisms are several-fold more pronounced in immature animals [19]. Substantial body of evidences, suggest that the developing brain shows a marked susceptibility to both changes in redox regulation and neuronal apoptosis, which may be related with this age-dependent injury vulnerability [20-24].

Mechanisms that cause neurological damage after PA might divided schematically into three metabolic phases [25-27]. Hypoxia leads to primary energy failure (phase 1). Shortly after re-oxygenation, aerobic metabolism is re-established (phase 2). However, as a result of a cascade of cellular mechanisms [28, 29], after 6-24 hours' mitochondrial energy production begins to fail one more time. This secondary energy failure (phase 3 ) is induced for $24-48$ hours after the hypoxic event. Damage that occurs during phase 3 is considerable and leads to deep cellular alterations [30]. Although many modifications induced by PA are related to biological reactions that result in partial recovery, PA also generates over-expression of several metabolic, molecular and cell cascade pathways, extending the energy deficit and redox imbalance, associated with further neuronal damage, to either apoptosis (with several associated genes such as Bcl2, Bax among others) or necrosis. Molecular cascades involved in the removal of damaged cells implying activation of ubiquitination, peroxisome, and caspases pathways.

On the other hand, redox imbalance is strongly connected with re-oxygenation after PA, resulting in both over-activation and inactivation of a number of buffering enzymes; including those modulating mitochondrial activity [31, 32]. Finally, resuscitation may even imply hyperoxemia, leading to a further production of ROS and redox imbalance, worsening brain injury [31, 32].

Finally, neuroimaging studies has shown that brain injury evolves over days, if not weeks [33], which has been substantiated in different animal models [34]. If time permits, various therapeutic interventions may be attempted as the injury evolves [35]. Clinical observation of babies with asphyxia and extensive laboratory research with experimental models led to a heuristic model in which hypoxia-ischemia triggers a delayed series of events that lead to brain cell death $[36,37]$. This period of latent interval suggested that post-insult interventions could be protective if started on time [36]. Being able to complement these findings with those regarding the elucidation of brain injury mechanisms could enable the identification of new therapeutic targets.

\section{REDOX REGULATION OF THIOREDOXIN PROTEIN FAMILY DURING PERINATAL ASPHYXIA BRAIN INJURY}

\subsection{Central Nervous System}

Reperfusion after an ischemic event leads to an increased production of ROS [39, 40], that have been proposed as causative agent for the death and degeneration of neurons following the insult [8, 40-42]. As we describe above, we have previously shown that Trxs family (and related) proteins are distributed in a wide region and cell-type specific manner in the rat and mouse CNS [38, 43], implying specific functions and a complex crosstalk between the Trxs family members. In addition, not all areas of the brain are equally vulnerable to hypoxia-ischemia. Among the most vulnerable areas are the superior brainstem, cerebellum, white matter and subcortical structures supplied by the distal branches of deep and superficial penetrating blood vessels, cerebral white matter at the zones between the major cerebral artery territories, CA1 region of the hippocampus, and neocortical layers 3,5 , and 6 [44-46] and retina.

Although no studies on Trxs family proteins in PA have been published, both the release of ROS and RNS have been demonstrated under these conditions [8], potentially leading to the deregulation of redox signaling, which could be responsible for the induction of apoptosis and de-differentiation in the CNS associated with long-term neurological deficits. The disruption of redox control or generally, the generation of ROS [47, 48] by uncoupling of the mitochondrial chain [49] and inflammation [50,51] were described as the most destructive causes of hypoxia/ischemia and reoxygenation injury.

Grx2-overexpressing HEK293 and HeLa cells exposed to hypoxia and reoxygenation showed less oxidative damage and increased survival and proliferation rates compared to wild-type controls [52]. Besides the anti-apoptotic function of mitochondrial Grx2a [53, 54], cytosolic Grx2c was recently shown to be essential for embryonic brain development. Zebrafishes with silenced expression of the oxidoreductase were characterized by the loss of the all types of neurons due to apoptosis and a developed 
axonal scaffold [55]. This data suggests that the isoforms of Grx2 could be crucial for the long-term regeneration of physiological redox signaling and the recovery of the affected tissues.

Previous studies have shown that the Trx family of proteins contributes to mechanisms of brain tolerance in early periods after exposure to stress [56, 87]. Cells have developed response mechanisms to cope with these low oxygen concentrations. HIF-1 and 2 constitute transcription factors that regulate the expression of more than 180 genes under hypoxic conditions [58]. The HIF-1 target ATIA (anti-TNFainduced-apoptosis) was shown to protect cells against hypoxia-induced apoptosis via Trx2 and the generation of ROS [59]. Moreover, hypoxia-induced mitochondrial ROS are essential for HIF activation [60, 61], regulate inflammatory responses via interleukin (IL-6) [62], and apoptosis via p38 phosphorylation [63]. Other studies suggested that over-expression of Trx1 leads to elevated HIF-1a levels in cells cultured under both normoxic and hypoxic conditions, whereas inhibition of TrxR1 activity blocked the activation of HIF-1a [64]. Trx1 leads to an induction of HIF-1 $1 \alpha$, possibly by activating Akt [65]. Trx1 might also be involved in depleting HIF-1a levels upon reoxygenation [66].

Hypoxic insults induce molecular and cellular changes, affecting cell morphology, cell polarity, osmoregulation, protein synthesis and the release of neurotransmitters $[67,68]$. The reoxygenation phase causes rapid changes in the redox properties of the affected tissue and an increase in the cytokine and chemokine levels, as well as the infiltration of immune cells [69]. Not surprisingly, members of the Trx family protect against ischemic injuries. Over-expression of
Trx1, Grx1, Grx2, and Prx2 attenuate ischemic damage of neurons [70-73]. Recently our group studied the expression and distribution of Trx family and related protein in the CNS. Trxs, Grxs and Prxs displayed a complex expression pattern following hypoxia/ischemia and reoxygenation event (Figure 1). Trx1 and Grx2 as late as 60 days after hypoxia/ischemia were expressed consistently. Over expression and silencing of these proteins in SH-SY5Y cells subjected to hypoxiareoxygenation showed that these proteins are required to maintain the normal neuronal phenotype. [74].

\subsection{Retina}

Retina is a tissue that undergoes high levels of stress due to its exposure to elevated oxygen levels and different light intensities [75]. Ganglion cells are the ones in charge of sending the visual input to the brain (visual cortex). This layer expresses every protein belonging to the Trx family proteins [38] and over expression of Trx 1 in retinal ganglion cells increases their survival after glutamate/buthionine sulfoximine treatment. In addition, Trx1 levels decreased after glaucoma induction and retinas that over expressed Trx1 and Trx2 showed a reduced loss of retinal ganglion cells after glaucoma induction [76]. On the other hand, retinal pigment epithelium (RPE) cells are located near the choroidal capillaries, making them particularly susceptible to ischemia or hypoxia [77]. Sugano et al. [78] shows that Trx2 has a protective effect in ARPE-19 cells treated with 4-hydroxynonenal (4-HNE) or C2-ceramide. Over expression of Trx2 reduced cell death induced by both agents in low concentrations. Moreover, Trx2 played a key role in cell viability through regulation of mitochondrial metabolic activity and Hsp70 expression

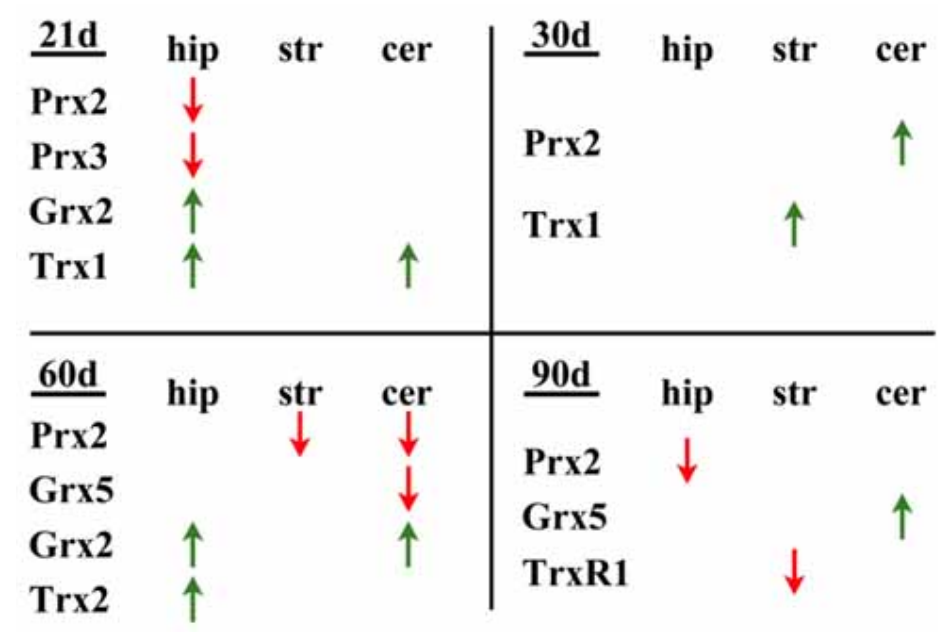

Figure 1: Scheme showing the time course of the expression of the Trx protein family after PA. 
On other hand, transgenic mice that express human Trx1 are less susceptible to light induced retinal damage [79]. Consistent with this view, Trx-1 expression is reduced after retinal damage [80], while Prx6 is also diminished in cell cultures submitted to a hypoxia event [81]. Caprioli et al. [82] reported a decrease in Trx1 levels more pronounced at 5 weeks after intra ocular pressure (IOP). In addition, Trx1 is also down-regulated after IOP in a rat glaucoma model, whereas its overexpression after IOP leads to an attenuated cell death [83]. The administration of $\mathrm{N}$ methyl-D-aspartate (NMDA) to mammalian eyes stimulates glutamate receptors and induces retinal damage mimicking retinal ischemia and glaucoma. An intravitreous Trx 1 injection effectively attenuates retinal cell damage induced by NMDA [84].

\subsection{Inflammatory Mediated Regulation During Oxygen Homeostasis Restoration}

Studies on the hypoxia signaling pathway have helped the concept that hypoxia can induce inflammation gain general acceptance. In persons with acute mountain sickness, for example, levels of circulating pro-inflammatory cytokines increase and vascular leakage causes pulmonary or cerebral edema. Hypoxia signaling and members of the nuclear factor $\mathrm{KB}$ (NF-KB) family of transcription factors regulate inflammation and orchestrate immune responses to achieve tissue homeostasis [85]. Members of this family interact with members of the HIF pathway in ways that link inflammation to hypoxia (Figure 2).

Ischemia reperfusion activates NF-kB in epithelial cells, which in turn increases the production of tumor necrosis factor $\alpha$ (TNF- $\alpha$ ), a pro-inflammatory cytokine, but simultaneously attenuates epithelial apoptotic hypoxic activated pathways. These pathways were related with the Thioredoxin protein family $[86,87]$. Choksi et al. [57] reported the identification of an NFkB-independent ATIA (anti-TNFa-induced apoptosis)Trx2 (Trx2) axis that inhibits TNFa- and hypoxiainduced apoptosis directly through elimination of excessive ROS. Current paradigm for inhibition of TNFa-induced apoptosis centers on NF-kB, which inhibits caspases and prevents prolonged JNK activation. In addition, the anti-apoptotic effect of NF-kB also was suggested to associate with the elimination of excessive ROS. In the same report, Choksi et al. [57] has shown that ATIA (anti-TNF $\alpha$-induced apoptosis) inhibits TNFa-induced apoptosis independently of NF$\mathrm{kB}$ through Trx2-mediated elimination of excessive ROS. These findings provide a novel hypothesis for inhibition of apoptosis induced by TNFa and other death signals by directly controlling ROS accumulation. The pleiotropic inflammatory cytokine TNFa regulates immune responses, inflammation, proliferation, and cell death (apoptosis and necrosis), and its regulation of apoptosis is mainly mediated by its membrane receptor 1 (TNF-R1). Upon TNFa stimulation, TNF-R1 trimer

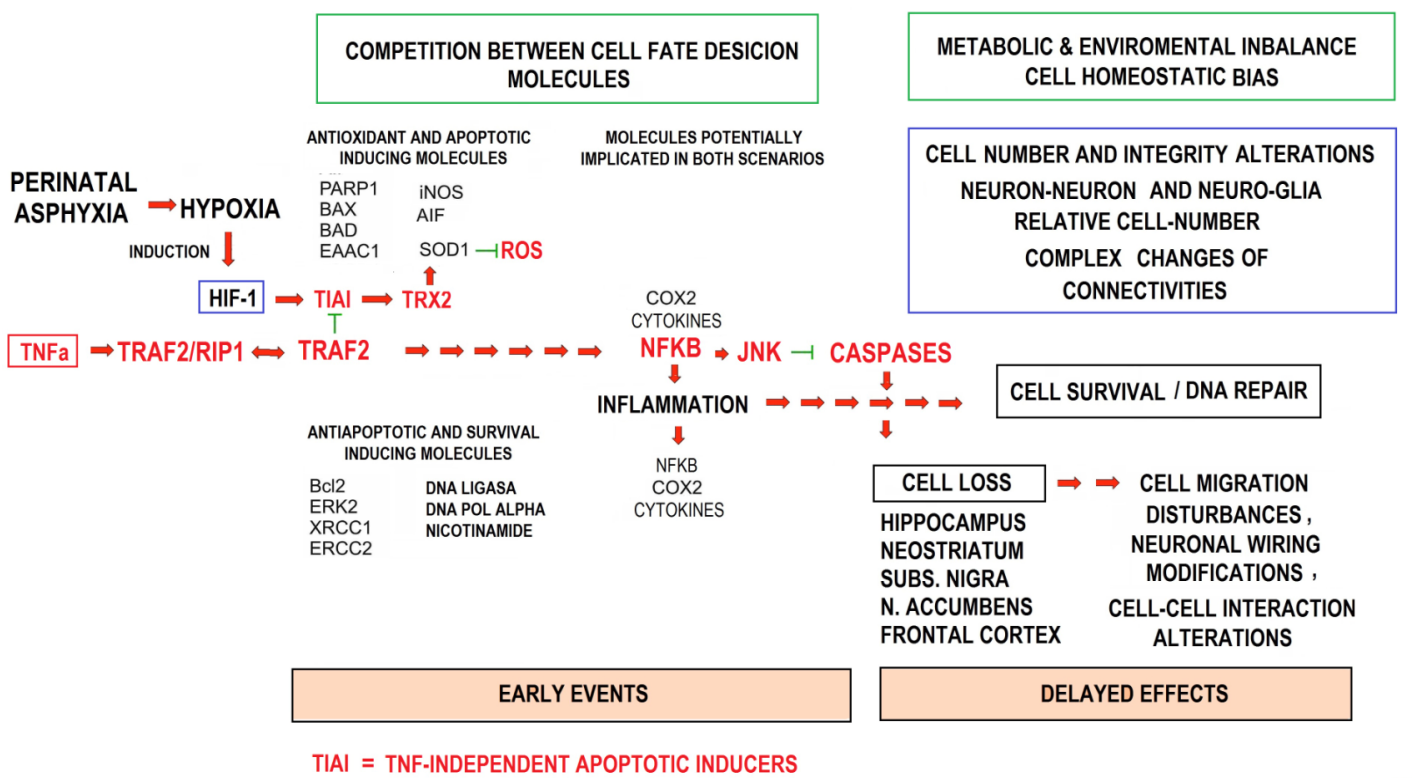

Figure 2: Schematic illustration of ATIA serving as a Link between inflammation and hypoxia: The ATIA-TRX2 axis inhibits apoptosis induced by both TNFa and low $\mathrm{O}_{2}$ through elimination of excessive ROS on mitochondria. This scenario rescues parenchymal cells from apoptosis. ATIA activity may be a key regulator in carcinogenesis because tumor cells usually take advantage from normal tissue under hypoxic conditions. Blockade of antitumor TNF- $\alpha$ cytotoxicity. 
recruits multiple adaptors such as, TRAF2, TRAF5, RIP1, CIAP1 and CIAP2 and other modulators or regulators such as Miz1 and the linear ubiquitin chain assembly complex [88, 89],

\subsection{Thioredoxin, Hypoxic-Ischemic Brain Injuries and Cognitive Alterations}

The hippocampus is commonly associated with learning and memory processes in mammals [90]. Previous studies have demonstrated that hypoxicischemic brain injuries can induce hippocampal neuron loss, which is implicated in spatial learning and memory deficits [91-93]. It has been demonstrated that transient bilateral common carotid arteries occlusion (BCCAO) can destroy more than $50 \%$ of hippocampal CA1 neurons [94] inducing learning and memory deficiencies tested in the Morris water maze [95, 96]. Redox regulatory proteins, such as Trxs, play a key role in the cellular response to redox imbalance, against brain damage induced by hypoxic-ischemic injuries [38]. Acute hypoxia leads to long-lasting behavioral consequences (motor, emotional and cognitive dysfunctions) in adult asphyctic rats [12]. However, only few works have studied the role of redox imbalance in the origin of behavioral alterations induced by hypoxic-ischemic injuries.

Regarding to Trx1, endogenous Trx 1 production is induced by cerebral ischemia where it is responsible for alleviation of oxidative damage. Exogenously administered recombinant human Trx1 (rhTrx1) can penetrate the blood brain barrier and exert a neuroprotective effect on injured neurons by the middle cerebral artery occlusion (MCAO) [97]. RhTrx1 may also promote neurogenesis and facilitate long-term recovery following bilateral common carotid artery occlusion (BCCAO). Recently, Tian et al. [98] have investigated the role of rhTrx1 in neurogenesis and its potential effect on learning and memory deficits measured in the Morris water maze following the BCCAO mouse model. Mice subjected to BCCAO treated with rhTrx1 before reperfusion showed shortened escape latencies in the learning phase and improvements in the spatial memory test. Moreover, rhTrx1 was effective in promoting neurogenesis in the dentate gyrus after cerebral ischemia and facilitating cognitive recovery of treated mice [99]. Previous studies have demonstrated that hippocampal neurogenesis could facilitate long-term potentiation and improve memory and learning [100, 101]. Hence, facilitation of endogenous neurogenesis could be a promising regenerative strategy for ischemic stroke treatment [100].

In other recent work, Yang et al. [101] studied the role of Trxs in neurodegenerative changes of rats subjected to chronic exposure to an intermittent hypoxia $(\mathrm{CIH})$ model. The most notable alterations were increased apoptosis in the CA1 region of the hippocampus and adjacent cortex, as well as substantial neuropsychological impairments of spatial learning in the Morris water maze. $\mathrm{ClH}$-rats showed impaired spatial learning and memory in the water maze (longer latencies to reach the target platform, reduced numbers of passes over the target platform, and smaller percentage of time spent in the target quadrant). Trx mRNA and protein levels were significantly decreased in the $\mathrm{ClH}$-hippocampus; meanwhile, an elevated apoptosis of hippocampal neurons of rats exposed to $\mathrm{ClH}$ was found. Rats, which displayed better performance in the spatial memory test, also showed higher levels of the Trx mRNA and protein in the hippocampus and lower number of apoptotic cells in the hippocampus [101]. Hence, Trx deficit may play a significant role in the impaired spatial learning and memory in rats exposed to $\mathrm{CIH}$ and this alteration may trigger the apoptosis of hippocampal neurons.

New studies are necessary to understand the relationships between redox system regulations in cognitive alterations after neuronal damage induced by hypoxic-ischemic episodes.

\section{CONCLUSIONS}

Several lines of evidences propose a key role of Trxs in the physiopathology of the brain ischemia insult. In addition, recently we have demonstrated that Trx-1 and Grx-2 have a key role on the different steps of the nervous cells differentiation. Therefore, Trx-s protein family appears a novel actor in the regulation of the mechanism involved in cell damage during PA.

\section{FUTURE DIRECTIONS}

Future experiments should be carried out to obtain new insights about Trx-s protein family function in the rescue of the nervous cells subjected to anoxic-hypoxic in order to design new therapeutic tools. These studies might introduce new insights, extremely useful to develop new therapeutic tools for PA and its complications. 


\section{REFERENCES}

[1] Lawn JE, Cousens S, Zupan J, Lancet Neonatal Survival Steering, 4 million neonatal deaths: when? Where? Why? Lancet 2005; 365: 891-900.

http://dx.doi.org/10.1016/S0140-6736(05)71048-5

[2] Amiel-Tison C, Ellison P. Birth asphyxia in the fullterm newborn: early assessment and outcome. Dev Med Child Neurol 1986; 28: 671-682. http://dx.doi.org/10.1111/j.1469-8749.1986.tb03914.x

Capani F, Saraceno GE, Botti V, Aon-Bertolino L, de Oliveira $\mathrm{DM}$, Barreto $\mathrm{G}$, et al . Protein ubiquitination in postsynaptic densities after hypoxia in rat neostriatum is blocked by hypothermia. Exp Neurol 2009; 219: 404-413. http://dx.doi.org/10.1016/j.expneurol.2009.06.007

[4] Miller SP, Ferriero DM. From selective vulnerability to connectivity: insights from newborn brain imaging. Trends Neurosci 2009; 32: 496-505. http://dx.doi.org/10.1016/.tins.2009.05.010

[5] Verger K, Junque C, Levin HS, Jurado MA, Perez-Gomez M, Bartres-Faz D, et al. Correlation of atrophy measures on MRI with neuropsychological sequelae in children and adolescents with traumatic brain injury. Brain inj. 2001; 15: 211-221.

\section{http://dx.doi.org/10.1080/02699050010004059}

[6] Yager JY, Thornhill JA. The effect of age on susceptibility to hypoxic-ischemic brain damage. Neurosci Biobehav Rev 1997; 21: 167-174. http://dx.doi.org/10.1016/S0149-7634(96)00006-1

[7] Halliwell B. Reactive oxygen species and the central nervous system. J Neurochem 1992; 59: 1609-1623. http://dx.doi.org/10.1111/j.1471-4159.1992.tb10990.x

[8] Capani F., Loidl CF, Aguirre F, Piehl L, Facorro G, Hager A, et al. Changes in reactive oxygen species (ROS) production in rat brain during global perinatal asphyxia: an ESR study. Brain Res. 2001; 914: 204-207. http://dx.doi.org/10.1016/S0006-8993(01)02781-0

[9] Capani F, Loidl CF, Piehl LL, Facorro G, De Paoli T, Hager A. Long term production of reactive oxygen species during perinatal asphyxia in the rat central nervous system: effects of hypothermia. Int J Neurosci 2003; 113: 641-654. http://dx.doi.org/10.1080/00207450390200099

[10] Capani F, Loidl F, López-Costa JJ, Selvin-Testa A, Saavedra JP. Ultrastructural changes in nitric oxide synthase immunoreactivity in the brain of rats subjected to perinatal asphyxia: neuroprotective effects of cold treatment. Brain Res. 1997; 775: 11-23. http://dx.doi.org/10.1016/S0006-8993(97)00714-2

[11] Saraceno GE, Bertolino ML, Galeano P, Romero JI, GarciaSegura LM, Capani F. Estradiol therapy in adulthood reverses glial and neuronal alterations caused by perinatal asphyxia. Exp Neurol 2010; 223: 615-622.

http://dx.doi.org/10.1016/j.expneurol.2010.02.010

[12] Galeano P, Blanco Calvo E, Madureira de Oliveira D, Cuenya L, Kamenetzky GV et al. Long-lasting effects of perinatal asphyxia on exploration, memory and incentive downshift. Int J Dev Neurosci 2011; 29: 609-619.

http://dx.doi.org/10.1016/j.ijdevneu.2011.05.002

[13] Saraceno GE, Ayala MV, Badorrey MS, Holubiec M, Romero $\mathrm{JI}$, Galeano P, et al. Effects of perinatal asphyxia on rat striatal cytoskeleton. Synapse 2012; 66: 9-19. http://dx.doi.org/10.1002/syn.20978

[14] Vannucci RC. Experimental models of perinatal hypoxicischemic brain damage, APMIS. Supplementum 1993; 40: 89-95.

[15] Rice JE 3rd, Vannucci RC, Brierley JC. The influence of immaturity on hypoxic-ischemic brain damage in the rat. Ann Neurol 1981; 9: 131-141. http://dx.doi.org/10.1002/ana.410090206
[16] Hagberg H, Bona E, Gilland E, Puka-Sundvall M. Hypoxiaischaemia model in the 7-day-old rat: possibilities and shortcomings. Acta Paediatr Suppl 1997; 422: 85-88. http://dx.doi.org/10.1111/j.1651-2227.1997.tb18353.x

[17] Hagberg H, Ichord R, Palmer C, Yager JY, Vannucci SJ Animal models of developmental brain injury: relevance to human disease. A summary of the panel discussion from the Third Hershey Conference on Developmental Cerebral Blood Flow and Metabolism. Dev Neurosci 2002; 24: 364-366. http://dx.doi.org/10.1159/000069040

[18] Vannucci RC, Vannucci SJ. Perinatal hypoxic-ischemic brain damage: evolution of an animal model. Dev Neurosci 2005 27: 81-86. http://dx.doi.org/10.1159/000085978

[19] Li H, Li Q, Du X, Sun Y, Wang X, Kroemer G, et al. Lithiummediated long-term neuroprotection in neonatal rat hypoxiaischemia is associated with antiinflammatory effects and enhanced proliferation and survival of neural stem/progenitor cells. J Cereb Blood Flow Metab 2011; 31: 2106-2115. http://dx.doi.org/10.1038/jcbfm.2011.75

[20] Zhu C, Wang X, Xu F, Bahr BA, Shibata M, Uchiyama $Y$, Hagberg $\mathrm{H}$ et al. The influence of age on apoptotic and other mechanisms of cell death after cerebral hypoxia-ischemia. Cell Death Differ 2005; 12: 162-176. http://dx.doi.org/10.1038/sj.cdd.4401545

[21] Bayir H, Kochanek PM, Kagan VE. Oxidative stress in immature brain after traumatic brain injury. Dev Neurosci 2006; 28: 420-431 http://dx.doi.org/10.1159/000094168

[22] Ikonomidou C, Kaindl AM. Neuronal death and oxidative stress in the developing brain. Antioxid Redox Signal 2011; 14: $1535-1550$ http://dx.doi.org/10.1089/ars.2010.3581

[23] Blomgren K, Leist M, Groc L. Pathological apoptosis in the developing brain. Apoptosis. 2007; 12: 993-1010. http://dx.doi.org/10.1007/s10495-007-0754-4

[24] Blomgren K, Zhu C, Hallin U, Hagberg H. Mitochondria and ischemic reperfusion damage in the adult and in the developing brain. Biochem Biophys Res Commun 2003; 304: 551-559.

http://dx.doi.org/10.1016/S0006-291X(03)00628-4

[25] Potts MB, Koh SE, Whetstone WD, Walker BA, Yoneyama T, Claus CP, Manvelyan HM, Noble-Haeusslein LJ. Traumatic injury to the immature brain: inflammation, oxidative injury, and iron-mediated damage as potential therapeutic targets, Neuro Rx 2006; 3: 143-153. http://dx.doi.org/10.1016/j.nurx.2006.01.006

[26] Gunn AJ, Gunn TR, de Haan HH, Williams CE, Gluckman PD. Dramatic neuronal rescue with prolonged selective head cooling after ischemia in fetal lambs. J Clin Invest 1997; 99: 248-256.

http://dx.doi.org/10.1172/JCl119153

[27] Roelfsema V, Bennet L, George S, Wu D, Guan J, Veerman M, Gunn AJ. Window of opportunity of cerebral hypothermia for postischemic white matter injury in the near-term fetal sheep, Journal of cerebral blood flow and metabolism. J Cereb Blood Flow Metab 2004; 24: 877-886. http://dx.doi.org/10.1097/01.WCB.0000123904.17746.92

[28] Hobbs C, Thoresen M, Tucker A, Aquilina K, Chakkarapani $\mathrm{E}$, Dingley J. Xenon and hypothermia combine additively, offering long-term functional and histopathologic neuroprotection after neonatal hypoxia/ischemia. Stroke. 2008; 39: 1307-1313. http://dx.doi.org/10.1161/STROKEAHA.107.499822

[29] Kittaka M, Giannotta SL, Zelman V, Correale JD, De Giorgio $\mathrm{CM}$, Weiss $\mathrm{MH}$, Zlokovic BH. Attenuation of brain injury and reduction of neuron-specific enolase by nicardipine in systemic circulation following focal ischemia and reperfusion in a rat model. J Neurosurg 1997; 87: 731-737. http://dx.doi.org/10.3171/jns.1997.87.5.0731 
[30] Vannucci RC, Towfighi J, Vannucci SJ. Secondary energy failure after cerebral hypoxia-ischemia in the immature rat. $\mathrm{J}$ Cereb Blood Flow Metab 2004; 24: 1090-1097. http://dx.doi.org/10.1097/01.WCB.0000133250.03953.63

[31] Gitto E, Reiter RJ, Karbownik M, Tan DX, Gitto P, Barberi S, Barberi I. Causes of oxidative stress in the pre- and perinatal period. Biol Neonate. 2002; 81: 146-157. http://dx.doi.org/10.1159/000051527

[32] Davis PG, Tan A, O'Donnell CPF, Schulze A. Resuscitation of newborn infants with $100 \%$ oxygen or air: a systematic review and meta-analysis. The Lancet 2004; 364: 13291333. http://dx.doi.org/10.1016/S0140-6736(04)17189-4

[33] McKinstry RC, Miller JH, Snyder AZ, Mathur A, Schefft GL, Almli CR, et al. A prospective, longitudinal diffusion tensor imaging study of brain injury in newborns. Neurology 2002; 59: 824-833. http://dx.doi.org/10.1212/WNL.59.6.824

[34] Nakajima W, Ishida A, Lange MS, Gabrielson KL, Wilson MA, et al. Apoptosis Has a Prolonged Role in the Neurodegeneration after Hypoxic Ischemia in the Newborn Rat. J Neurosci 2000; 20: 7994-8004.

[35] Ferriero DM. Timing is everything-delaying therapy for delayed cell death. Dev Neurosci 2002; 24: 349-351. http://dx.doi.org/10.1159/000069048

[36] Johnston MV, Nakajima W, Hagberg $H$. Mechanisms of hypoxic neurodegeneration in the developing brain. Neurosci 2002; 8: 212-220. http://dx.doi.org/10.1177/1073858402008003007

[37] Fatemi A, Wilson MA, Johnston MV. Hypoxic-ischemic encephalopathy in the term infant. Clin Perinatol 2009; 36: 835-858. http://dx.doi.org/10.1016/j.clp.2009.07.011

[38] Bharath S, Hsu M, Kaur D, Rajagopalan S, Andersen JK. Glutathione, iron and Parkinson's disease. Biochem Pharmacol 2002; 64: 1037-1048.

http://dx.doi.org/10.1016/S0006-2952(02)01174-7

[39] Dringen R. Glutathione metabolism and oxidative stress in neurodegeneration. Eur J Biochem 2000; 267: 4903. http://dx.doi.org/10.1046/j.1432-1327.2000.01651.x

[40] Rodriguez VM, Del Razo LM, Limon-Pacheco JH, Giordano $M$, Sanchez-Pena LC, Uribe-Querol E et al. Glutathione reductase inhibition and methylated arsenic distribution in Cd1 mice brain and liver. Toxicol Sci 2005; 84: 157-166. http://dx.doi.org/10.1093/toxsci/kfi057

[41] Singh IN, Sullivan PG, Deng Y, Mbye LH, Hall ED. Time course of post-traumatic mitochondrial oxidative damage and dysfunction in a mouse model of focal traumatic brain injury: implications for neuroprotective therapy. J Cereb Blood Flow Metab 2006; 26: 1407-1418.

http://dx.doi.org/10.1038/sj.jcbfm.9600297

[42] Bains JS, Shaw CA. Neurodegenerative disorders in humans: the role of glutathione in oxidative stress-mediated neuronal death. Brain Res Brain Res Rev 1997; 25: 335-358. http://dx.doi.org/10.1016/S0165-0173(97)00045-3

[43] Torreilles F, Salman-Tabcheh S, Guerin M, Torreilles J. Neurodegenerative disorders: the role of peroxynitrite. Brain Res 1999; 30: 153-163.

http://dx.doi.org/10.1016/S0165-0173(99)00014-4

[44] Dirnagl U, Becker K, Meisel A. Preconditioning and tolerance against cerebral ischaemia: from experimental strategies to clinical use. Lancet Neurology 2009; 8: 398-412. http://dx.doi.org/10.1016/S1474-4422(09)70054-7

[45] Martensson J, Meister A. Glutathione deficiency decreases tissue ascorbate levels in newborn rats: ascorbate spares glutathione and protects. PNAS 1991; 88: 4656-4660. http://dx.doi.org/10.1073/pnas.88.11.4656

[46] Aon-Bertolino ML, Romero JI, Galeano P, Holubiec M, Badorrey MS, Saraceno GE, et al. Thioredoxin and glutaredoxin system proteins-immunolocalization in the rat central nervous system. Biochim Biophys Acta 2011; 1810: 93-110. http://dx.doi.org/10.1016/j.bbagen.2010.06.011

[47] Flamm ES, Demopoulos HB, Seligman ML, Poser RG, Ransohoff J. Free radicals in cerebral ischemia. Stroke 1997; 9: 445-447.

http://dx.doi.org/10.1161/01.STR.9.5.445

[48] Phillis JW. A "radical" view of cerebral ischemic injury. Prog Neurobiol 1994; 42: 441-448.

http://dx.doi.org/10.1016/0301-0082(94)90046-9

[49] Alonso-Alconada D, Hilario E, Alvarez FJ, Alvarez A Apoptotic cell death correlates with ROS overproduction and early cytokine expression after hypoxia-ischemia in fetal lambs. Reprod Sci 2012; 19: 754-763. http://dx.doi.org/10.1177/1933719111432868

[50] Godoy JR, Funke M, Ackermann W, Haunhorst P, Oesteritz $\mathrm{S}$, Capani F, et al. Redox atlas of the mouse. Immunohistochemical detection of glutaredoxinperoxiredoxin-, and thioredoxin-family proteins in various tissues of the laboratory mouse. Biochim Biophys Acta 2011; 1810: 2-92. http://dx.doi.org/10.1016/j.bbagen.2010.05.006

[51] Arbelaez A, Castillo M, Mukherji SK. Diffusion-weighted MR imaging of global cerebral anoxia. AJNR Am J Neuroradiol 1999; 20: 999-1007.

[52] Busl KM, Greer DM. Hypoxic-ischemic brain injury: pathophysiology, neuropathology and mechanisms. Neuro Rehabilitation 2010; 26: 5-13.

[53] Chalela JA, Wolf RL, Maldjian JA, Kasner SE. MRI identification of early white matter injury in anoxic-ischemic encephalopathy. Neurology 2001; 56: 481-485. http://dx.doi.org/10.1212/WNL.56.4.481

[54] Bonventre JV, Weinberg JM. Recent advances in the pathophysiology of ischemic acute renal failure. Nephron Clin Pract 2003; 14: 2199-2210.

http://dx.doi.org/10.1097/01.asn.0000079785.13922.f6

[55] Wardle EN. Cellular oxidative processes in relation to renal disease. Am J Nephrol 2005; 25: 13-22. http://dx.doi.org/10.1159/000083477

[56] Baines CP. The mitochondrial permeability transition pore and ischemia-reperfusion injury. Basic Res Cardiol. 2009; 104: 181-188.

http://dx.doi.org/10.1007/s00395-009-0004-8

[57] Hutchens MP, Dunlap J, Hurn PD, Jarnberg PO. Renal ischemia: does sex matter? Anesth Analg 2008; 107: 239249. http://dx.doi.org/10.1213/ane.0b013e318178ca42

[58] Weight SC, Bell PR, Nicholson ML. Renal ischaemia-reperfusion injury. The Br J Surg 1996; 83: 162-170. http://dx.doi.org/10.1002/bjs.1800830206

[59] Godoy JR, Oesteritz S, Hanschmann EM, Ockenga W, Ackermann W, Lillig $\mathrm{CH}$. Segment-specific overexpression of redoxins after renal ischemia and reperfusion: protective roles of glutaredoxin 2, peroxiredoxin 3, and peroxiredoxin 6 . Free Radic Biol Med 2011; 51: 552-561.

http://dx.doi.org/10.1016/j.freeradbiomed.2011.04.036

[60] Enoksson M, Fernandes AP, Prast S, Lillig CH, Holmgren A, Orrenius $S$. Overexpression of glutaredoxin 2 attenuates apoptosis by preventing cytochrome c release. Biochem Biophys Res Commun 2005; 327: 774-779. http://dx.doi.org/10.1016/j.bbrc.2004.12.067

[61] Lillig $\mathrm{CH}$, Lonn ME, Enoksson M, Fernandes AP, Holmgren A. Short interfering RNA-mediated silencing of glutaredoxin 2 increases the sensitivity of HeLa cells toward doxorubicin and phenylarsine oxide. PNAS 2004; 101: 13227-13232. http://dx.doi.org/10.1073/pnas.0401896101

[62] Brautigam L, Schutte LD, Godoy JR, Prozorovski T, Gellert M et al. Vertebrate-specific glutaredoxin is essential for brain 
development. PNAS 2011; 108: 20532-20537.

http://dx.doi.org/10.1073/pnas.1110085108

[63] Hu X, Weng Z, Chu CT, Zhang L, Cao G, Gao Y, Signore A, et al. Peroxiredoxin-2 protects against 6-hydroxydopamineinduced dopaminergic neurodegeneration via attenuation of the apoptosis signal-regulating kinase (ASK1) signaling cascade. J Neurosci 2011; 31: 247-261.

http://dx.doi.org/10.1523/JNEUROSCl.4589-10.2011

[64] Stroev SA, Tyul'kova El, Glushchenko TS, Tugoi IA, Samoilov MO, Pelto-Huikko M. Thioredoxin-1 expression levels in rat hippocampal neurons in moderate hypobaric hypoxia. Neurosci Behav Physiol 2009; 39: 1-5. http://dx.doi.org/10.1007/s11055-008-9091-5

[65] Choksi S, Lin Y, Pobezinskaya $Y$, Chen L, Park C, Morgan $\mathrm{M}$, et al. A HIF-1 target, ATIA, protects cells from apoptosis by modulating the mitochondrial thioredoxin. TRX2. Mol Cell 2011; 42: 597-609. http://dx.doi.org/10.1016/j.molcel.2011.03.030

[66] Mansfield KD, Guzy RD, Pan Y, Young RM, Cash TP, Schumacker PT, et al. Mitochondrial dysfunction resulting from loss of cytochrome c impairs cellular oxygen sensing and hypoxic HIF-alpha activation. Cell Metab 2005; 1: 393399.

http://dx.doi.org/10.1016/j.cmet.2005.05.003

[67] Sanjuan-Pla A, Cervera AM, Apostolova N, Garcia-Bou R, Victor VM, Murphy MP et al. A targeted antioxidant reveals the importance of mitochondrial reactive oxygen species in the hypoxic signaling of HIF-1alpha. FEBS letters 2005; 579: 2669-2674.

http://dx.doi.org/10.1016/j.febslet.2005.03.088

[68] Pearlstein DM, Ali MH, Mungai PT, Hynes KL, Gewertz BL, Schumacker PT. Role of mitochondrial oxidant generation in endothelial cell responses to hypoxia, Arterioscler Thromb Vasc Biol 2002; 22: 566-573. http://dx.doi.org/10.1161/01.ATV.0000012262.76205.6A

[69] Kulisz A, Chen N, Chandel NS, Shao Z, Schumacker PT. Mitochondrial ROS initiate phosphorylation of p38 MAP kinase during hypoxia in cardiomyocytes. Am J Physiol Lung Cell Mol Physiol 2002; 282: L1324-1329.

http://dx.doi.org/10.1152/ajplung.00326.2001

[70] Moos PJ, Edes K, Cassidy P, Massuda E, Fitzpatrick FA. Electrophilic prostaglandins and lipid aldehydes repress redox-sensitive transcription factors p53 and hypoxiainducible factor by impairing the selenoprotein thioredoxin reductase. J Biol Chem 2003; 278: 745-750.

http://dx.doi.org/10.1074/jbc.M211134200

[71] Zhou J, Damdimopoulos AE, Spyrou G, Brune B. Thioredoxin 1 and thioredoxin 2 have opposed regulatory functions on hypoxia-inducible factor-1alpha. J Biol Chem 2007; 282: 7482-7490.

http://dx.doi.org/10.1074/jbc.M608289200

[72] Jewell UR, Kvietikova I, Scheid A, Bauer C, Wenger RH, Gassmann M. Induction of HIF-1alpha in response to hypoxia is instantaneous. FASEB J 2001; 15: 1312-1314.

[73] Dirnagl U, ladecola C, Moskowitz MA. Pathobiology of ischaemic stroke: an integrated view. Trends Neurosci 1999; 22: 391-397.

http://dx.doi.org/10.1016/S0166-2236(99)01401-0

[74] Romero JI, Hanschmann EM, Gellert M, Eitner S, Holubiec $\mathrm{MI}$, Blanco-Calvo $\mathrm{E}$, et al. Thioredoxin 1 and glutaredoxin 2 contribute to maintain the phenotype and integrity of neurons following perinatal asphyxia. Biochim Biophys Acta 2015; 1850: $1274-85$ http://dx.doi.org/10.1016/j.bbagen.2015.02.015

[75] Garg TK, Chang JY. Oxidative stress causes ERK phosphorylation and cell death in cultured retinal pigment epithelium: prevention of cell death by AG126 and 15-deoxydelta 12, 14-PGJ2. BMC Ophthalmol 2003; 3: 5. http://dx.doi.org/10.1186/1471-2415-3-5
[76] Munemasa Y, Ahn JH, Kwong JM, Caprioli J, Piri N. Redox proteins thioredoxin 1 and thioredoxin 2 support retinal ganglion cell survival in experimental glaucoma. Gene Ther 2009; 16: 17-25.

http://dx.doi.org/10.1038/gt.2008.126

[77] Li KR, Zhang ZQ, Yao J, Zhao YX, Duan J, Cao C, et al. Ginsenoside Rg-1 protects retinal pigment epithelium (RPE) cells from cobalt chloride $(\mathrm{CoCl} 2)$ and hypoxia assaults. PloS one 2013; 8: e84171.

http://dx.doi.org/10.1371/journal.pone.0084171

[78] Sugano E, Murayama N, Takahashi M, Tabata K, Tamai M, Tomita $\mathrm{H}$. Essential role of thioredoxin 2 in mitigating oxidative stress in retinal epithelial cells. J Ophthalmol 2013; (13): 185825 http://dx.doi.org/10.1155/2013/185825

[79] Tanito M, Masutani H, Nakamura H, Ohira A, Yodoi J. Cytoprotective effect of thioredoxin against retinal photic injury in mice. Invest Ophthalmol Vis Sci 2002; 43: 11621167.

[80] Tulsawani R, Kelly LS, Fatma N, Chhunchha B, Kubo E, Kumar A et al. Neuroprotective effect of peroxiredoxin 6 against hypoxia-induced retinal ganglion cell damage. BMC Neurosci 2010; 11: 125.

http://dx.doi.org/10.1186/1471-2202-11-125

[81] Caprioli J, Ishii Y, Kwong JM: Retinal ganglion cell protection with geranylgeranylacetone, a heat shock protein inducer, in a rat glaucoma model. Trans Am Ophthalmol Soc 2003; 101: 39-50

[82] Knippenberg R, Lawn JE, Darmstadt GL, Begkoyian G, Fogstad $\mathrm{H}$, Walelign $\mathrm{N}$, et al. Lancet Neonatal Survival Steering, Systematic scaling up of neonatal care in countries. Lancet 2005; 365: 1087-1098. http://dx.doi.org/10.1016/S0140-6736(05)74233-1

[83] Al-Macki N, Miller SP, Hall N, Shevell M. The spectrum of abnormal neurologic outcomes subsequent to term intrapartum asphyxia. Pediatr Neurol 2009: 41: 399-405. http://dx.doi.org/10.1016/i.pediatrneurol.2009.06.001

[84] Ceballos A, Remes Lenicov F, Sabatte J, Rodriguez Rodrigues C, Cabrini M, Jancic C, Raiden $S$ et al. Spermatozoa capture HIV-1 through heparan sulfate and efficiently transmit the virus to dendritic cells. J Exp Med 2009; 206: 2717-2733. http://dx.doi.org/10.1084/jem.20091579

[85] Miller SP, Marinkovich VA, Riege DH, Sell WJ, Baker DL, Eldredge NT, et al. Application of the MAST Immunodiagnostic System to the determination of allergenspecific IgE. Clin Chem 1984; 30: 1467-1472.

[86] Brown CR, Higgins KW, Frazer K, Schoelz LK, Dyminski JW Marinkovich VA, et al. Simultaneous determination of total $\operatorname{lgE}$ and allergen-specific $\mathrm{IgE}$ in serum by the MAST chemiluminescent assay system. Clin Chem 1985; 31: 15001505.

[87] Ross DM, Uecker SL, Powell SR, Miller SP, Bean JA The impact of group and individual therapy on socialization of residents in an institutional setting. Issues Ment Health Nurs 1980; 2: 33-42.

http://dx.doi.org/10.3109/01612848009012503

[88] Squire LR. Memory and the hippocampus: a synthesis from findings with rats, monkeys, and humans. Psychol Rev 1992; 99: 195-231.

http://dx.doi.org/10.1037/0033-295X.99.2.195

[89] Bendel O., Alkass K., Bueters T, von Euler M, von Euler G. Reproducible loss of CA1 neurons following carotid artery occlusion combined with halothane-induced hypotension Brain Res 2005; 1033: 135-142. http://dx.doi.org/10.1016/j.brainres.2004.11.033

[90] Chen G, Chen KS, Knox J, Inglis J, Bernard A, Martin SJ, et al. A learning deficit related to age and beta-amyloid plaques in a mouse model of Alzheimer's disease. Nature 2000; 408 : 
975-979.

http://dx.doi.org/10.1038/35046031

[91] Hartman RE, Lee JM, Zipfel GJ, Wozniak DF. Characterizing learning deficits and hippocampal neuron loss following transient global cerebral ischemia in rats. Brain Res 2005; 1043: 48-56.

http://dx.doi.org/10.1016/j.brainres.2005.02.030

[92] West MJ, Coleman PD, Flood DG, Troncoso JC. Differences in the pattern of hippocampal neuronal loss in normal ageing and Alzheimer's disease. Lancet 1994; 344: 769-772. http://dx.doi.org/10.1016/S0140-6736(94)92338-8

[93] Zhang HP, Yuan LB, Zhao RN, Tong L, Ma R, Dong HL, Xiong L. Isoflurane preconditioning induces neuroprotection by attenuating ubiquitin-conjugated protein aggregation in a mouse model of transient global cerebral ischemia. Anesth Analg 2010; 111: 506-514. http://dx.doi.org/10.1213/ANE.0b013e3181e45519

[94] Block F. Global ischemia and behavioural deficits. Prog Neurobiol 1999; 58: 279-295 http://dx.doi.org/10.1016/S0301-0082(98)00085-9

[95] Raber J, Fan Y, Matsumori Y, Liu Z, Weinstein PR, Fike JR, Liu J. Irradiation attenuates neurogenesis and exacerbates ischemia-induced deficits. Ann Neurol 2004; 55: 381-389. http://dx.doi.org/10.1002/ana.10853

[96] Hattori I, Takagi Y, Nakamura H, Nozaki K, Bai J, Kondo N, et al. Intravenous administration of thioredoxin decreases brain damage following transient focal cerebral ischemia in mice. Antioxid Redox Signal 2004; 6: 81-87. http://dx.doi.org/10.1089/152308604771978372

[97] Tian L, Nie H, Zhang $\mathrm{Y}$, Chen $\mathrm{Y}$, Peng Z, Cai M, et al. Recombinant human thioredoxin-1 promotes neurogenesis and facilitates cognitive recovery following cerebral ischemia in mice. Neuropharmacol 2014; 77: 453-464. http://dx.doi.org/10.1016/j. neuropharm.2013.10.027

[98] Abraham WC, Logan B, Greenwood JM, Dragunow M. Induction and experience-dependent consolidation of stable long-term potentiation lasting months in the hippocampus. $\mathrm{J}$ Neurosci 2002; 22: 9626-9634.

[99] Deng W, Aimone JB, Gage FH. New neurons and new memories: how does adult hippocampal neurogenesis affect learning and memory? Nature reviews. Neurosci 2010; 11: 339-350. http://dx.doi.org/10.1038/nrn2822

[100] Schmidt-Hieber C, Jonas P, Bischofberger J. Enhanced synaptic plasticity in newly generated granule cells of the adult hippocampus. Nature 2004; 429: 184-187. http://dx.doi.org/10.1038/nature02553

[101] Yang XH, Liu HG, Liu X, Chen JN. Thioredoxin and impaired spatial learning and memory in the rats exposed to intermittent hypoxia. Chin Med J 2012; 125: 3074-3080.

Received on 15-11-2015

Accepted on 27-01-2016

Published on 29-04-2016

http://dx.doi.org/10.15379/2409-3564.2016.03.01.02

(C) 2016 Capani et al.; Licensee Cosmos Scholars Publishing House.

This is an open access article licensed under the terms of the Creative Commons Attribution Non-Commercial License (http://creativecommons.org/licenses/by-nc/3.0/), which permits unrestricted, non-commercial use, distribution and reproduction in any medium, provided the work is properly cited. 